\title{
PENGARUH PENERAPAN MODEL PEMBELAJARAN CREATIVE PROBLEM SOLVING TERHADAP KEMAMPUAN KOMUNIKASI MATEMATIS BERDASARKAN SELF REGULATED LEARNING SISWA SEKOLAH MENENGAH PERTAMA PEKANBARU
}

\author{
Sri Ulfa Alawiyah ${ }^{1}$, Lies Andriani ${ }^{2}$, Depi Fitraini ${ }^{3}$ \\ ${ }^{1,2,3}$ Universitas Islam Negeri Sultan Syarif Kasim Riau \\ ${ }^{1}$ sriulfa.alawiyah@ @tudents.uin-suska, ${ }^{2}$ lies.andriani@uin-suska.ac.id, ${ }^{3}$ depi.fitraini@ uin-suska.ac.id
}

\begin{abstract}
ABSTRAK
Penelitian ini bertujuan untuk mengetahui prbedaan kemampuan komunikasi matematis antara siswa yang mengikuti pembelajaran dengaen model Creative Problem Solving (CPS) dengan siswa yang tidak mengikuti pembelajaran dengan model Creative Problem Solving (CPS) jika berdasarkan self regulated learning siswa SMPIT Az Zuhra Islamic School Pekanbaru. Penelitian ini merupakan penelitian Quasi Eksperimen dan desain yang digunakan adalah The Nonequivalent Pretest-Posttest Control Group Design. Teknik sampel yang digunakan dalam penelitian ini adalah Purposive Sampling. Analisis data yang digunakan peneliti yaitu dengan menggunakan uji anova dua jalan. Berdasarkan hasil analisis data dapat diambil kesimpulan bahwa: 1) Terdapat perbedaan kemampuan komunikasi matematis antara siswa yang mengikuti pembelajaran dengan model CPS dengan siswa yang tidak mengikuti pembelajaran dengan model CPS, 2) Terdapat perbedaan kemampuan komunikasi matematis siswa yang mengikuti pembelajaran dengan model CPS dengan siswa yang tidak mengikuti pembelajaran dengan model CPS jika berdasarkan self regulated learning siswa, 3) Tidak terdapat pengaruh interaksi penerapan model pembelajaran dan self regulated learning terhadap kemampuan komunikasi matematis siswa. Dengan demikian, secara umum dapat disimpulkan bahwa penerapan model pembelajaran CPS berpengaruh terhadap kemampuan komunikasi matematis berdasarkan self regulated learning siswa Sekolah Menengah Pertama Pekanbaru.
\end{abstract}

Kata Kunci : Model Pembelajaran Creative Problem Solving, Kemampuan Komunikasi Matematis, Self Regulated Learning.

\section{ABSTRACT}

This study investigated if there is a significant difference in mathematical communication ability between the students taught by using Creative Problem Solving Learning Model and without using Creative Problem Solving Learning Model based on self-regulated learning at Az Zuhra Islamic Junior High School Pekanbaru. This study was a Quasi Experimental Research using the Nonequivalent Pretest-Posttest Control Group Design. The research sample was selected utilizing purposive sampling. The data in this study were analyzed employing a two-way ANOVA. From the data analysis, it revealed that 1) there is a significant difference in mathematical communication between the students taught by using Creative Problem Solving Learning Model and without using Creative Problem Solving Learning Model 2) there is a significant difference in mathematical communication between the students taught by using Creative Problem Solving Learning Model and without using Creative Problem Solving Learning Model based on self-regulated learning 3) there is no interaction effect of Creative Problem Solving Learning Model and self-regulated learning on the students' mathematical communication. It can be concluded that Creative Problem Solving Learning Model affects the students' mathematical communication ability based on self-regulated learning at Junior High School Pekanbaru 
Keywords: Creative Problem Solving Learning Model, Mathematical Communication Ability, SelfRegulated Learning).

\section{PENDAHULUAN}

Matematika merupakan pelajaran yang dipelajari di berbagai jenjang pendidikan, mulai dari jenjang pendidikan dasar hingga jenjang perkuliahan. Isrok'atun \& Rosmala (2018) menyatakan bahwa matematika merupakan suatu ilmu yang mempelajari bagaimana proses berpikir secara rasional dan masuk akal dalam memperoleh konsep, dikatakan sebagai ilmu karena keberadaannya dapat dipelajari dari berbagai fenomena. Hal tersebut merupakan salah satu alasan yang menunjukkan matematika merupakan pelajaran yang sangat penting dalam dunia pendidikan.

NCTM (National Council of Teacher of Mathematics) menyatakan bahwa komunikasi matematis adalah bagian esensial dari matematika dan pendidikan matematika, tanpa komunikasi yang baik, maka perkembangan matematika akan terhambat. Sejalan dengan itu, menurut Permendikbud Nomor 21 Tahun 2016 tentang Standar Isi Pendidikan Dasar dan Menengah menetapkan bahwa kompetensi yang harus dicapai pada pelajaran matematika salah satunya memiliki kemampuan mengomunikasikan gagasan matematika dengan jelas. Oleh karena itu, bahwa kemampuan komunikasi matematis merupakan salah satu kemampuan yang sangat diperlukan dalam mempelajari matematika. Hodiyanto (2017) menyatakan bahwa kemampuan komunikasi matematis adalah kemampuan siswa dalam menyampaikan ide matematika baik secara lisan maupun tulisan, komunikasi lisan seperti diskusi dan menjelaskan sedangkan komunikasi tulisan seperti mengungkapkan ide matematika melalui gambar, grafik, tabel, persamaan, ataupun dengan bahasa siswa sendiri. Menurut Idris (2005) bahasa matematika merupakan alat yang penting dalam komunikasi, oleh karena itu setiap guru dan siswa perlu menguasai bahasa matematika dengan baik supaya segala perbincangan dalam kelas bisa di pahami oleh kedua pihak. Namun fakta yang terjadi di lapangan, hasil belajar matematika siswa belum sepenuhnya sesuai dengan tujuan yang diharapkan.

Rendahnya kemampuan matematika siswa, bisa jadi salah satu penyebabnya adalah kurangnya kemampuan siswa dalam melakukan komunikasi matematika. Adapun hasil penelitian yang dilakukan beberapa peneliti yaitu Utami dan Azmi yang hasilnya membuktikan bahwa kemampuan komunikasi merupakan salah satu masalah matematika yang perlu diberikan solusi untuk mengatasi masalah tersebut. 
Menurut Utami (2015) siswa masih kesulitan dalam membuat gambar yang merupakan salah satu indikator kemampuan komunikasi matematis. Menurut Azmi (2017) ditemukan rendahnya kemampuan komunikasi matematis siswa khususnya komunikasi tertulis matematis. Berdasarkan tes yang peneliti lakukan di SMPIT Az Zuhra Islamic School Pekanbaru diperoleh hasil masih rendahnya kemampuan komunikasi matematis siswa pada materi himpunan. Hasil tes tersebut menunjukkan pengetahuan siswa pada soal dengan indikator komunikasi matematis masih rendah, hal ini berdasarkan permasalahan sebagai berikut:

1. Banyaknya siswa yang belum mampu menyatakan situasi matematika ke dalam bentuk diagram dan aljabar (sekitar 60\%)

2. Masih kurangnya siswa dalam memberikan penjelasan terhadap model matematika (sekitar 66,7\%).

3. Masih kurangnya siswa dalam membuat pertanyaan dari situasi yang diberikan disertai alasan (sekitar 86,7\%).

Berdasarkan permasalahan yang terjadi, perlu adanya upaya perbaikan yang dilakukan untuk mengatasi kurangnya kemampuan komunikasi matematis siswa. Solusi yang dilakukan dengan memilih model pembelajaran yang sesuai. Salah satu model pembelajaran yang mampu mengatasi masalah kemampuan komunikasi matematis adalah model pembelajaran Creative Problem Solving (CPS). Hal ini sebagaimana pendapat Istarani \& Ridwan (2014) bahwa model pembelajaran CPS memiliki beberapa kelebihan salah satunya yaitu pembelajaran CPS melatih dan menumbuhkan kreativitas, kognitif tinggi, kritis, komunikasiinteraksi, keterbukaan, dan sosialisasi. Pada langkah CPS mengungkapkan pendapat, siswa diberi kebebasan dalam mengungkapkan gagasan/ide-idenya dalam memecahkan masalah dengan itu siswa bisa mengomunikasikan gagasan atau idenya. Begitupun hasil penelitian yang dilakukan Apiati \& Fatimah (2017) yang menyatakan bahwa model pembelajaran CPS memberikan hasil lebih baik sehingga terjadi peningkatan kemampuan komunikasi matematis pada siswa.

Selain kemampuan komunikasi matematis, kemandirian belajar (self regulated learning) juga perlu dimiliki siswa. Hendriana, Rohaeti, \& Sumarmo (2017) menyebutkan bahwa satu sub faktor penting dari keadaan individu yang mempengaruhi belajar adalah kemandirian belajar (self regulated learning). Menurut Desmita (2014) kemandirian berarti 
adanya inisiatif untuk mengatasi masalah yang dihadapi. Oleh karena itu adanya inisiatif tersebut akan mendorong siswa dalam menyelesaikan suatu permasalahan matematika salah satunya terhadap persoalan matematika dalam hal kemampuan komunikasi matematis. Hal ini sejalan dengan hasil penelitian yang dilakukan oleh Sumartono \& Karmila (2017) yang menunjukkan bahwa adanya hubungan antara kemampuan komunikasi matematis setiap siswa dengan kemandirian siswa.

Berdasarkan latar belakang yang telah diuraikan sebelumnya, maka rumusan masalah dalam penelitian ini adalah: 1) Apakah terdapat perbedaan kemampuan komunikasi matematis antara siswa yang mengikuti pembelajaran dengan model Creative Problem Solving (CPS) dengan siswa yang tidak mengikuti pembelajaran dengan model Creative Problem Solving (CPS)?, 2) Apakah terdapat perbedaan kemampuan komunikasi matematis siswa yang mengikuti pembelajaran dengan model Creative Problem Solving (CPS) dengan siswa yang tidak mengikuti pembelajaran dengan model Creative Problem Solving (CPS) Jika berdasarkan self regulated learning siswa ?, 3) Apakah terdapat interaksi penerapan model pembelajaran dan self regulated learning terhadap kemampuan komunikasi matematis siswa?

\section{METODE PENELITIAN}

Penelitian ini merupakan penelitian Quasi Eksperimen dan desain yang digunakan adalah The Nonequivalent Pretest-Posttest Control Group Design. Secara rinci desain penelitian tersebut disajikan pada table 1 berikut.

Tabel 1. Rancangan Penelitian

\begin{tabular}{ccc}
\hline $\mathrm{O}$ & $\mathrm{X}$ & $\mathrm{O}$ \\
\hline $\mathrm{O}$ & - & $\mathrm{O}$ \\
\hline
\end{tabular}

Keterangan:

$\mathrm{X}=$ Perlakuan/treatment yang diberikan (variabel independen)

$\mathrm{O}=$ Pretest/Posttest (variabel dependen yang diobservasi)

Populasi dalam penelitian ini adalah siswa kelas VII SMPIT Az Zuhra Islamic School Pekanbaru. Teknik pengambilan sampel yang digunakan dalam penelitian ini adalah teknik purposive sampling. Purposive sampling adalah teknik penentuan sampel dengan pertimbangan tertentu (Sugiyono, 2014). Teknik sampel ini digunakan peneliti karena guru yang mengajar matematika setiap kelasnya sama, hal ini memungkinkan kedua kelas tersebut mendapat perlakuan yang sama pada proses pembelajaran. Hal ini juga berdasarkan 
keterangan dari guru matematika kelas VII, bahwa kedua kelas tersebut diyakini memiliki karakteristik yang sama dan memungkinkan kedua kelas tersebut bersifat homogen. Sampel dalam penelitian ini adalah siswa kelas VII.C sebagai kelas eksperimen dan kelas VII.B sebagai kelas kontrol. Kelas eksperimen merupakan kelas yang mendapat pembelajaran dengan model pembelajaran Creative Problem Solving (CPS) sedangkan kelas kontrol merupakan kelas yang tidak mengikuti pembelajaran dengan model Creative Problem Solving (CPS). Siswa pada kelas eksperimen sebanyak 31 siswa sedangkan kelas kontrol sebanyak 27 siswa.

Sebelum pembelajaran dilaksanakan pada kelas eksperimen maupun kelas kontrol diberikan pretest kemampuan komunikasi matematis untuk menunjukkan bahwa kedua kelas tersebut memiliki kemampuan awal komunikasi matematis yang homogen. Di akhir pembelajaran pada kelas eksperimen maupun kelas kontrol diberikan posttest kemampuan komunikasi matematis untuk mengetahui sejauh mana kemampuan komunikasi matematis siswa setelah diberikan perlakuan.

Indikator kemampuan komunikasi matematis siswa dalam penelitian ini yaitu: 1) Menyatakan situasi matematika atau peristiwa sehari-hari ke dalam model matematika dan menyelesaikannya; 2) Menyatakan model matematika dengan gambar, tabel, grafik, diagram, aljabar; 3) Memberi penjelasan terhadap model matematika; 4) Menyusun pertanyaan terhadap situasi yang diberikan disertai alasan. Adapun indikator self regulated learning yaitu: 1) Berinisiatif belajar dengan atau tanpa bantuan orang lain; 2) Mendiagnosis kebutuhan belajarnya sendiri; 3) Merumuskan tujuan belajar; 4) Mengidentifikasi sumber belajar yang dapat digunakannya; 5) Memonitor, mengatur, dan mengontrol belajar; 6) Memilih dan menerapkan strategi belajar; 7) Mengevaluasi hasil belajar

\section{HASIL DAN PEMBAHASAN}

Pada bagian ini akan dijelaskan data hasil pretest dan posttest kemampuan komunikasi matematis. Analisis data yang digunakan yaitu uji-t dan anova dua jalan. Uji-t digunakan untuk mengetahui apakah terdapat perbedaan antara kemampuan awal komunikasi matematis siswa di kelas eksperimen dengan siswa di kelas kontrol. Sedangkan anova dua jalan digunakan untuk menganalisis data hipotesis 1, 2 dan 3. Sebelum dilakukan uji statistika, data 
hasil kemampuan komunikasi matematis terlebih dahulu dianalisis dengan uji prasyarat yaitu uji normalitas dan homogenitas.

\section{Kemampuan Komunikasi Matematis (Pretest)}

Uji normalitas dilakukan dengan bantuan excel dengan rumus lilifors, dengan kriteria

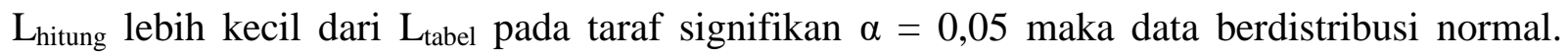
Hasil uji normalitas nilai data pretest terangkum pada tabel 2 berikut.

\section{Tabel 2. Uji Normalitas Pretest}

\begin{tabular}{ccc}
\hline Kelas & $\mathrm{L}_{\text {hitung }}$ & $\mathrm{L}_{\text {tabel }}$ \\
\hline VII B & 0,160 & 0,173 \\
VII C & 0,104 & 0,159 \\
\hline
\end{tabular}

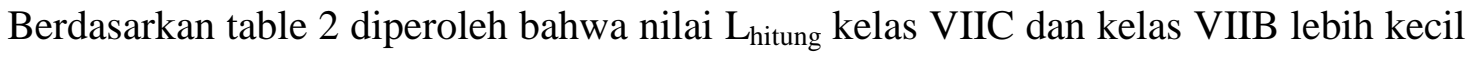
dari dari nilai $\mathrm{L}_{\text {tabel }}$ pada taraf signifikan $\alpha=0,05$ berdasarkan kriteria maka kelas VIIC dan VIIB berdistribusi normal.

Setelah diketahui data berdistribusi normal dilanjutkan dengan uji homogenitas kedua kelas. Uji homogenitas dilakukan bantuan excel dengan kriteria $F_{\text {hitung }}$ lebih kecil dari $F_{\text {tabel }}$, maka data berdistribusi homogen. Hasil uji homogenitas nilai data pretest pada tabel 3 berikut.

Tabel 3. Uji Homogenitas Pretest

\begin{tabular}{cc}
\hline $\mathrm{F}_{\text {hitung }}$ & $\mathrm{F}_{\text {tabel }}$ \\
\hline 1,14 & 1,87 \\
\hline
\end{tabular}

Berdasarkan table 3 diperoleh bahwa nilai $F_{\text {hitung }}$ lebih kecil dari dari nilai $F_{\text {tabel }}$ pada taraf signifikan $\alpha=0,05$ berdasarkan kriteria maka kedua kelas homogen.

Setelah dilakukan uji normalitas dan homogenitas diperoleh bahwa data berdistribusi normal dan homogen maka selanjutnya yang dilakukan adalah uji-t. Jika $t_{\text {hitung }}$ lebih kecil dari $\mathrm{t}_{\text {tabel }}$ pada taraf signifikan $\alpha=0,05$ maka tidak terdapat perbedaan kemampuan. Hasil uji-t nilai data pretest terangkum pada tabel 4 berikut.

\begin{tabular}{cc} 
& Tabel 4. Uji-T Pretest \\
\hline $\mathrm{t}_{\text {hitung }}$ & $\mathrm{t}_{\text {tabel }}$ \\
\hline 0,41 & 2,00 \\
\hline
\end{tabular}

Berdasarkan table 4 diperoleh bahwa nilai $t_{\text {hitung }}$ lebih kecil dari dari nilai $t_{\text {tabel }}$ pada taraf signifikan $\alpha=0,05$ berdasarkan kriteria maka kedua kelas tidak memiliki perbedaan kemampuan. 


\section{Kemampuan Komunikasi Matematis (Posttest)}

Uji normalitas dilakukan dengan bantuan excel dengan rumus lilifors, dengan kriteria $\mathrm{L}_{\text {hitung }}$ lebih kecil dari $\mathrm{L}_{\text {tabel }}$ pada taraf signifikan $\alpha=0,05$ maka data berdistribusi normal. Hasil uji normalitas nilai data pretest terangkum pada tabel 5 berikut.

Tabel 5. Uji Normalitas Posttest

\begin{tabular}{ccc}
\hline Kelas & $\mathrm{L}_{\text {hitung }}$ & $\mathrm{L}_{\text {tabel }}$ \\
\hline Kontrol & 0,120 & 0,173 \\
\hline Eksperimen & 0,098 & 0,159 \\
\hline
\end{tabular}

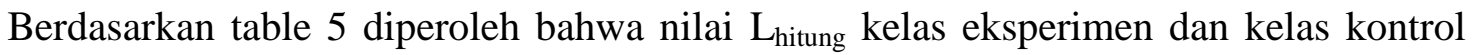
lebih kecil dari dari nilai $\mathrm{L}_{\text {tabel }}$ pada taraf signifikan $\alpha=0,05$ berdasarkan kriteria maka kelas eksperimen dan kontrol berdistribusi normal.

Setelah diketahui data berdistribusi normal dilanjutkan dengan uji homogenitas kedua kelas. Uji homogenitas dilakukan bantuan excel dengan kriteria $F_{\text {hitung }}$ lebih kecil dari $F_{\text {tabel }}$, maka data berdistribusi homogen. Hasil uji homogenitas nilai data pretest pada tabel 6 berikut.

Tabel 6. Uji Homogenitas Posttest

\begin{tabular}{cc}
\hline $\mathrm{F}_{\text {hitung }}$ & $\mathrm{F}_{\text {tabel }}$ \\
\hline 1,12 & 1,90 \\
\hline
\end{tabular}

Berdasarkan table 6 diperoleh bahwa nilai $F_{\text {hitung }}$ lebih kecil dari dari nilai $F_{\text {tabel }}$ pada taraf signifikan $\alpha=0,05$ berdasarkan kriteria maka kedua kelas homogen.

\section{Uji Anova Dua Jalan}

Uji yang dilakukan dengan kriteria jika nilai signifikan yang diperoleh lebih kecil dari

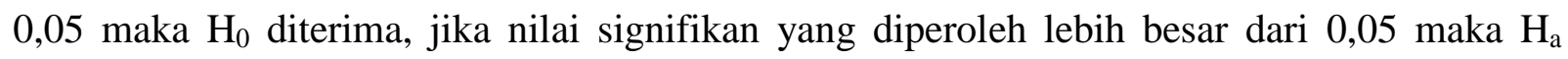
diterima. Berikut hasil uji anova dua jalan terangkum pada tabel 7 berikut.

Tabel 7. Hasil Uji Anova Dua Jalan

\begin{tabular}{ccc}
\hline Variansi & $\mathrm{F}_{\mathrm{h}}$ & $\mathrm{F}_{\mathrm{t}}$ \\
\hline Antar A ( model pembelajaran) & 5,15 & 4,03 \\
Antar B (self regulated learning) & 4,66 & 3,18 \\
Interaksi AxB & 2,18 & 3,18 \\
\hline
\end{tabular}

Terdapat perbedaan kemampuan komunikasi matematis antara siswa yang mengikuti pembelajaran dengan model Creative Problem Solving (CPS) dengan siswa yang tidak mengikuti pembelajaran dengan model Creative Problem Solving (CPS). Hal ini dapat dilihat dari nilai $\mathrm{F}(\mathrm{A})_{\text {hitung }}>\mathrm{F}(\mathrm{A})_{\text {tabel }}$ atau $5,15>4,03$ pada taraf signifikan 5\%, yang berarti $\mathrm{H}_{\mathrm{a}}$ 
diterima dan $\mathrm{H}_{0}$ ditolak. Maka dapat disimpulkan bahwa model pembelajaran Creative Problem Solving mempengaruhi kemampuan komunikasi matematis siswa.

Terdapat perbedaan kemampuan komunikasi matematis siswa yang mengikuti pembelajaran dengan model Creative Problem Solving (CPS) dengan siswa yang tidak mengikuti pembelajaran dengan model Creative Problem Solving (CPS) jika berdasarkan self regulated learning siswa. Hal ini dapat dilihat dari nilai $\mathrm{F}(\mathrm{B})_{\text {hitung }}>\mathrm{F}(\mathrm{B})_{\text {tabel }}$ atau 4,66 > 3,18 pada taraf signifikan $5 \%$, yang berarti $\mathrm{H}_{\mathrm{a}}$ diterima dan $\mathrm{H}_{0}$ ditolak.

Tidak terdapat pengaruh interaksi penerapan model pembelajaran dan self regulated learning terhadap kemampuan komunikasi matematis siswa. Hal ini dapat dilihat dari nilai $\mathrm{F}(\mathrm{AxB})_{\text {hitung }}<\mathrm{F}(\mathrm{AxB})_{\text {tabel }}$ atau 2,18 $<3,18$ yang berarti $\mathrm{H}_{0}$ diterima dan $\mathrm{H}_{\mathrm{a}}$ ditolak.

Berdasarkan analisis data tentang kemampuan komunikasi matematis siswa pada pokok bahasan perbandingan bahwa mean menunjukkan kemampuan komunikasi matematis yang menggunakan model pembelajaran CPS lebih tinggi dari siswa yang tidak menggunakan model pembelajaran CPS. Hasil analisis tersebut mendukung hipotesis masalah yang pertama, yaitu terdapat perbedaan kemampuan komunikasi matematis antara siswa yang mengikuti pembelajaran dengan model CPS dengan siswa yang tidak mengikuti pembelajaran dengan model CPS. Analisis data menunjukkan mean kelas eksperimen dan mean kelas kontrol secara berturut adalah 55,19 dan 41,70. Sebagaimana yang dikatakan Sugiyono (2014) bahwa jika terdapat perbedaan yang signifikan antara kelompok eksperimen dan kelompok kontrol, maka perlakuan yang diberikan berpengaruh secara signifikan. Berikut penyajian diagram terhadap mean kemampuan komunikasi matematis kelas eksperimen dan kontrol.

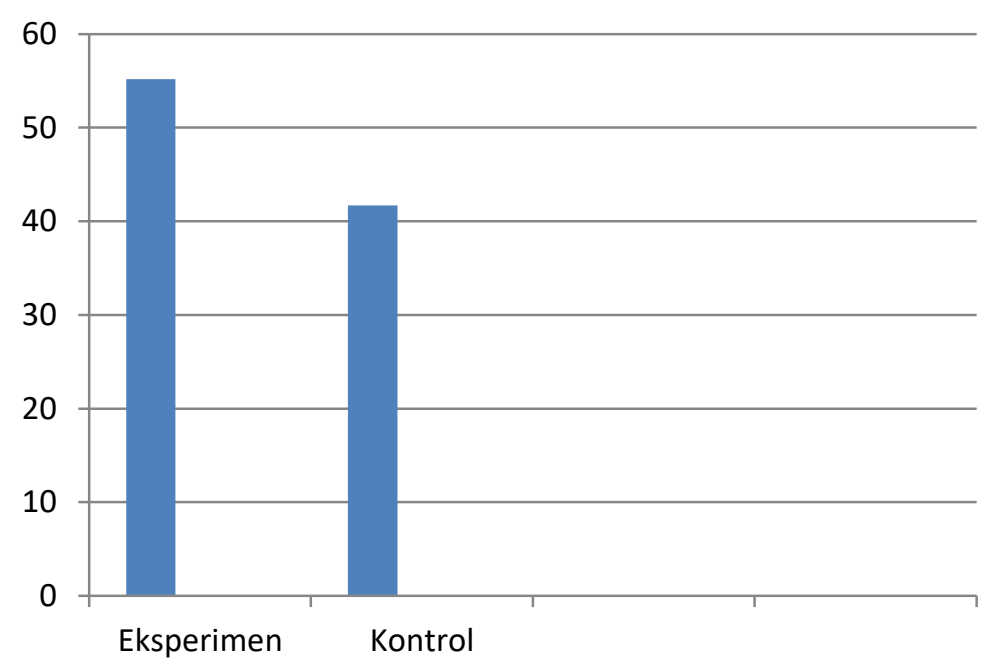

Gambar.1 Diagram Mean Kelas Kemampuan Komunikasi Matematis 
Pada hipotesis kedua, diperoleh $\mathrm{F}(\mathrm{B})_{\text {hitung }}>\mathrm{F}(\mathrm{B})_{\text {tabel }}$ atau 4,66 > 3,18 yang berarti $\mathrm{H}_{\mathrm{a}}$ diterima dan $\mathrm{H}_{0}$ ditolak. Hal ini menunjukkan bahwa terdapat perbedaan kemampuan komunikasi matematis antara siswa yang memiliki self regulated learning tinggi, sedang dan rendah. Berdasarkan rata-rata hasil kemampuan komunikasi matematis siswa untuk tiap kategori self regulated learning yang belajar dengan menggunakan model CPS dan yang tidak belajar dengan menggunakan model CPS menunjukkan hasil yang berbeda. Pada kategori self regulated learning tinggi, siswa kelas eksperimen dan kontrol berturut-turut mendapatkan rata-rata sebesar 69,00 dan 41,50. Kemudian pada kategori self regulated learning sedang, siswa kelas eksperimen dan kontrol berturut-turut mendapatkan rata-rata sebesar 62,39 dan 44,85. Pada kategori self regulated learning rendah, siswa kelas eksperimen dan kontrol berturut-turut mendapatkan rata-rata sebesar 34,67 dan 21,00. Dengan demikian dapat disimpulkan bahwa terdapat perbedaan kemampuan komunikasi matematis siswa yang mengikuti pembelajaran dengan model Creative Problem Solving (CPS) dengan siswa yang tidak mengikuti pembelajaran dengan model Creative Problem Solving (CPS) jika berdasarkan self regulated learning siswa.

Pada hipotesis ketiga, diperoleh $\mathrm{F}(\mathrm{AxB})_{\text {hitung }}<\mathrm{F}(\mathrm{AxB})_{\text {tabel }}$ atau $2,18<3,18$ yang berarti $\mathrm{H}_{0}$ diterima dan $\mathrm{H}_{\mathrm{a}}$ ditolak, sehingga dapat disimpulkan bahwa tidak terdapat interaksi penerapan model pembelajaran dan self regulated learning terhadap kemampuan komunikasi matematis siswa. Hasil penelitian ini juga relevan dengan penelitian yang dilakukan oleh Sari dan Fitraini (2018) yang menyatakan tidak terdapat interaksi antara model pembelajaran ditinjau dari kemandirian belajar terhadap kemampuan komunikasi matematis siswa.

\section{KESIMPULAN}

Berdasarkan hasil pembahasan di atas dapat disimpulkan bahwa: 1) Terdapat perbedaan kemampuan komunikasi matematis antara siswa yang mengikuti pembelajaran dengan model Creative Problem Solving (CPS) dengan siswa yang tidak mengikuti pembelajaran dengan model Creative Problem Solving (CPS), 2) Terdapat perbedaan kemampuan komunikasi matematis siswa yang mengikuti pembelajaran dengan model Creative Problem Solving (CPS) dengan siswa yang tidak mengikuti pembelajaran dengan model Creative Problem Solving (CPS) jika berdasarkan self regulated learning siswa, 3) 
Tidak terdapat interaksi penerapan model pembelajaran dan self regulated learning terhadap kemampuan komunikasi matematis siswa.

\section{UCAPAN TERIMAKASIH}

Penulis mengucapkan terima kasih kepada Rektor Universitas Sultan Syarif Kasim Riau yang telah memberikan izin untuk melaksanakan penelitian ini. Selain itu penulis juga mengucapkan terima kasih kepada segenap tim Pengelola Jurnal Pasundan yang telah memberikan kesempatan kepada penulis untuk mempublikasikan karya ilmiahnya.

\section{REFERENSI}

Apiati, V., \& Fatimah, A. (2017). Peningkatan Kemampuan Komunikasi matematik peserta didik yang menggunakan model creative problem solving (CPS). JP3M jurnal Penelitian Pendidikan dan Pengajaran Matematika, 3(1), 71-76.

Azmi, M. P. (2017). Penerapan Pendekatan Concrete-Representational-Abstract (CRA) Berbasis Instuisi Untuk Meningkatkan Kemampuan Komunikasi Matematik Siswa SMP. Aksioma, 6(1), 68-80.

Desmita. (2014). Psikologi Perkembangan Peserta Didik. Bandung: Remaja Rosdakarya.

Hendriana, H., Rohaeti, E. E., \& Sumarmo, U. (2017). Hard Skills dan Soft Sklills Matematik Siswa. Bandung: Refika Aditama.

Hodiyanto. (2017). Kemampuan Komunikasi Matematis Dalam Pembelajaran Matematika. AdMathEdu, 7(1), 11-12.

Idris, N. (2005). Pedagogi Dalam Pendidikan Matematik. Kuala Lumpur: Utusan Publications \& Distributors Sdn Bhd.

Isrok'atun \& Rosmala, A. (2018). Model-model Pembelajaran Matematika. Jakarta: Bumi Aksara.

Istarani \& Ridwan, M. (2014). 50 Tipe Pembelajaran Kooperatif. Medan: Media Persada.

Menteri Pendidikan dan Kebudayaan Republik Indonesia. (2016). Peraturan Menteri Pendidikan dan Kebudayaan Republik Indonesia Nomor 21 Tahun 2016 tentang Standar Isi Pendidikan Dasar dan Menengah. Jakarta: KEMENDIKBUD.

NCTM. (2000). Principles and Standards for School Mathematics. The United State of America: Library of Congress Cataloguing.

Sari, S. R., \& Fitraini, D. (2018). Pengaruh Penerapan Model Pembelajaran Kooperatif Tipe Jigsaw terhadap Kemampuan Komunikasi Matematis ditinjau dari Kemandirian Belajar Siswa Sekolah Menengah Pertama Pekanbaru. Journal for Research in Mathematics Learning, 1(1), 183-188.

Sugiyono. (2014). Metode Penelitian Pendidikan Kuantitatif Kualitatif, Dan R\&D. Bandung: Alfabeta. 
Sumartono \& Karmila, M. (2017). Kemampuan Komunikasi Matematis dan Kemandirian Siswa dalam Pembelajaran Matematika Menggunakan Model Knisley di Kelas VIII. Edu-Mat Jurnal Pendidikan Matematika, 5(2), 218-225.

Utami, C., Dwijanto, \& Djuniadi. (2015). Pembelajaran Model Generatif Dengan Strategi Group Investigation Untuk Meningkatkan Kemampuan Komunikasi Matematis siswa. UJMER, 4(1), 26-33. 